\title{
PRESENCE AND THE FUTURE TENSE IN HORACE'S ODES*
}

Abstract: Horace is sometimes said to profess in the Odes a "poetics of presence," a philosophical or aesthetic orientation that privileges the here and now. This article examines how such an orientation toward the present might interact with the poet's use of the future tense and especially with those future verbs that seem to postpone focal events. It is concluded that the Odes' many gestures toward the future, from simple imperatives to the postponement of entire symposia, serve to problematize presence and to dramatize, in concert with other features of the collection, the anxious feeling that time is moving too quickly.

C(T That is a Horatian ode?" wondered Heinze in his seminal essay Die Horazische Ode. He concluded, famously, that a Horatian ode is "an address to a person thought of as present." In the century since this influential work appeared, presence in its various forms has been a central issue in the study of Horace's lyric poetry, frequently discussed and sometimes passionately contested, yet Heinze's thesis stills beguiles with its intuitive simplicity: if the Odes, as is generally believed, praise and affirm the bounty of the present moment, why should the poet not strive to create and represent presence in the scene and setting of individual poems? On the other hand, presence of this most evident sort is, as subsequent scholars have shown, in fact quite elusive, and the temporality of the Odes is complicated by a number of factors, most notably the poet's frequent gestures toward the future. The goal of this article is, first of all, to explore how the definition of lyric presence has evolved and gained complexity in critical discourse on the Odes since Heinze; secondly, to examine how address,

${ }^{*}$ For their assistance with this project at various stages and for their generous support of my work on the Odes in general, I owe an incalculable debt of gratitude to Jenny Strauss Clay, A.J. Woodman, John Miller and David Kovacs, eminent and devoted Horatians; I am also grateful to Coulter George for enlightening me on the subtleties of Indo-European linguistics, to audience members at CAMWS in Oklahoma City for entertaining an earlier version of this paper and to the anonymous readers of $C J$ for their constructive remarks. All errors remain my own.

${ }^{1}$ Heinze (1923) 160: "Die horazische Ode ist, wie wir sahen, Ansprache an eine als gegenwärtig gedachte Person." Heinze’s essay was reprinted in 1938 in a book of collected essays, Vom Geist des Römertums; an English translation appears in Lowrie (2009a) 11-32.

THE CLASSICAL JOURNAL 109.3 (2014) 333 - 361 
directive expressions and verbs in the future tense accord with the "poetics of presence;" and, finally, to determine the aesthetic and philosophical implications of futurity in Horatian lyric. It will be argued that the poet, particularly in the sympotic poems, deploys directives and verbs in the future tense to problematize rather than affirm presence and to dramatize rather than compass the fleeting and continuous nature of time.

For Heinze, of course, presence is straightforwardly dramatic — he imagines each ode sung or spoken before an explicit or implicit addressee in a notional space. Heinze adjusts his interpretations of individual odes to fit his model in clever but occasionally procrustean ways: he speculates, for instance, that 1.17 need not be an invitation, but could be sung to Tyndaris as she arrives in the country, or that 3.29, which likewise appears to invite the addressee to Tibur, could be sung by the poet on a visit to Maecenas in Rome. ${ }^{2}$ Such strained readings vividly demonstrate a difficult fact about the Horatian ode as Heinze defines it: it is rarely self evident that, first of all, the addressee must be thought of as present and, secondly, that the utterance of the poem must be located in a specific situation or scene. As Citroni, one of Heinze's many critics, has pointed out, truly unambiguous dramatic presence is extremely rare in the Odes; only occasionally are there clear and unmistakable markers of ongoing action (as in 1.27 , where the speaker reacts to a drunken brawl erupting around him), or deixis through demonstrative pronouns pointing to something seen by both the speaker and the addressee. ${ }^{3}$ Only five examples of the latter may be cited ( $h u c$ 2.3.13, hac ... pinu 2.11.13-14, harum arborum 2.14.22, non hoc semper erit liminis aut aquae / caelestis patiens latus 3.10.19-20, hic paries 3.26.6), of which Barchiesi in his discussion of the issue admits only the second and the third. ${ }^{4}$ Address, on the other hand, is "ubiquitous." 5 The reader who attends to such details is

\footnotetext{
${ }^{2}$ Heinze (1923) 155. Fraenkel (1957) 227 n. 1 calls this particular interpretation "an unmistakable product of Systemszwang [the tendency to systematize]."

${ }^{3}$ Cf. Citroni (1995) 274-5. Citroni's focus, however, is not really the same as Heinze's; while Heinze discusses primarily the formal aspects of address, Citroni is interested in the broader notion of "literary communication." Cf. Citroni (1995) 273: "Né gli oggetti né gli dèi possono essere destinatari di una comunicazione letteraria, mentre un personaggio pùo essere proposto dal testo come destinatario privilegiato di un carme anche se il carme non parla di lui in seconda persona, ma ne parla in terza persona o comunque lo coinvolge, anche indirettamente."

${ }^{4}$ Barchiesi (2007) 156 does not discuss the other three examples, but presumably he considers them to be merely "bland' deictic pointers."

${ }^{5}$ Cf. Barchiesi (2007) 156. Statistics bear this out: only six poems, out of eighty-eight in Odes 1 3, lack a named or anonymous addressee: 1.34, 1.36, 2.15, 3.2, 3.5 and 3.9. Unusual circumstances
} 
frequently marooned at a middle point: he can conceive, as Heinze insists he conceive, of a situation of discourse in which the speaker of the poem hails an addressee who stands in the speaker's presence, yet only occasionally is such a conception the inevitable or even the most plausible reading of the poem.

So Heinze's notion of dramatic presence can only by tendentious means be made to fit Horace's lyric poetry; indeed, the conceptual space of a Horatian ode is often, as Citroni and Barchiesi show, vaguely defined and even deemphasized. The contours of the dramatic situation are, in most cases, indefinite and open to question. But presence does not thereby disappear entirely. Most subsequent discussions of Horatian lyric, even those which explicitly disagree with Heinze, tend to define the Horatian ode as the dramatization of a discrete and focal present moment, whether this moment resides in a narrative sequence or recurs as an iterative abstraction of the lyric voice, harbinger of poetic immortality. ${ }^{6}$ Quinn, a vociferous critic of Heinze's approach, prefers the term "dramatic monologue," which deemphasizes the direct interaction between speaker and addressee, but retains the idea that each ode has an implicit scene or setting whose contours the reader is tasked to reconstruct. ${ }^{7}$ Such an understanding of Horace is characteristic of the New Criticism, which typically figures a lyric poem as "an utterance overheard" and consequently enjoins the reader to reconstruct not only the dramatic situation but also the attitudes and concerns of the speaker. ${ }^{8}$ Thus Johnson suggests that every lyric poem enacts a present moment which the reader must perforce narrate and recover. ${ }^{9}$ Some odes, defined by

explain most of these exceptional cases. 1.34 may anticipate the address of Fortuna at 1.35.1; the mention of Numida at 1.36 .3 potentially suggests a "shadow addressee" for this poem. 3.2 and 3.5, as two of the Roman odes, seem to partake of the invocation in the first stanza of 3.1 of an audience of boys and girls (favete linguis... virginibus puerisque canto 3.1.2-4). 3.9 follows different conventions, being a dialogue between two characters, and the lack of direct address does not lead to any confusion as to who is speaking to whom. In truth, it is only 2.15 that stands out as being a truly "monologic" utterance which is not addressed to anyone in particular.

${ }^{6}$ The idea that modern lyric belongs especially to the present time may be influential here; cf. e.g. Culler (2002) 152: "Proverbial definition calls the lyric a monument to immediacy." Genette (1992) 46-8 lists six literary critics from the 19th and 20th century (Schelling, Jean Paul, Hegel, Vischer, Erskine and Jakobson) who connect the genre of lyric with the present time.

${ }^{7}$ Cf. Quinn (1963) 87.

${ }^{8}$ The idea that lyric poetry is "overheard" is usually ascribed to John Stuart Mill; cf. Culler (2002) 137. Culler (1985) 38 argues that imagining or reconstructing this context for the lyric utterance "is, roughly, the approach to the lyric expounded and exemplified by the New Criticism."

${ }^{9}$ Johnson (1982) 35: "behind every lyric, sometimes vaguely sketched, sometimes clearly defined, is a story that explains the present moment of discourse." 
Quinn as "verse epistles," may not indicate this present moment with any evident spatial or scenic markers, but even such poems offer a focal present around which the reader may construct a story: spatial presence merely gives way to presence in a linear sequence of events. ${ }^{10}$ In other words, "here" in poetic space gives way to "now" in narrative time. ${ }^{11}$

The shortcomings of this theory of lyric have been amply demonstrated by Culler in his essay "Apostrophe," which pointedly opposes apostrophic lyric to narrative and calls into question the New Critical practice of placing lyric poems on a narrative continuum. ${ }^{12}$ This does not mean, however, that lyric lacks a focal present, but merely that its present cannot be narrated: the lyrical and apostrophic present is "timeless" because it resists the confines of temporal sequence. Fittingly, and sometimes explicitly under the influence of Culler's argument, more recent scholarship on Horatian lyric often takes it as a goal to seek for presence a still more supple definition, a definition expansive enough to embrace the so-called "temporality" of writing, "a special temporality which is the set of all moments at which writing can say "now." 13 Davis, for instance, emphatically rejects the idea that "unity of place is, or should be, the organizing principle of a Horatian ode." ${ }^{14}$ In the case of the endlessly disputed setting of Odes 1.9, for example, he allows for an "expanded time frame," an inclusive "now," which encompasses not only the "time of speaking" but also the time of one's youth, or perhaps any time before death (153). Yet the injunction to enjoy the present, far from being marginalized, is in fact rescued, in Davis' words, from "trivialization" by an appreciation of its "symbolic dimensions" (145). The present remains central to Horace's "ethos" of conviviality; as Davis writes, "the sapiens, by fully accepting his own irreversibility, undertakes to defy time by a

\footnotetext{
${ }^{10}$ Cf. Quinn (1963) 86-7.

${ }^{11}$ The fact that adverbial hic, like English 'here', can "indicate both discursive and physical locations" (Lowrie (2006) 117) already points to the potential blurring of spatial and narrative presence in lyric poetry.

${ }^{12}$ Cf. Culler (2002) 148-9 (originally published in 1983, but reprinted in 2002 with a new introduction.): "if one brings together in a poem a boy, some birds, a few blessed creatures, and some mountains, meadows, hills and groves, one tends to place them in a narrative where one thing leads to another; the events which form ask to be temporally located ... But if one puts into a poem thou shepherd boy, ye blessed creatures, ye birds, they are immediately associated with what might be called a timeless present but is better seen as a temporality of writing ... So located by apostrophes, birds, creatures, boys etc. resist being organized into events that can be narrated ..."

${ }^{13}$ Cf. Culler (2002) 149.

${ }^{14}$ Cf. Davis (1991) 152.
} 
gesture that valorizes the present at the expense of both past and future" (245). The poetic present, inexplicable in terms of physical space and linear time, may, in Davis' view, be preserved as an abstraction and a symbol.

Lowrie takes a similarly expansive view of presence in the Odes. She states plainly her premise that "lyric time is the hic et nunc." 15 This is indeed a complex hic et nunc: it involves the past and the future and moves to replace the author's temporal presence with the iterative and immortal presence of the abstract reader. Nonetheless "Horace's now" remains the "pivot" of the poem, because "the rhetorical construction of Horatian lyric privileges the present moment." ${ }^{16}$ Not without success, either, as the poet seems to achieve, through writing, "the eternal recreation of the presence of song" (70). Mindt echoes Lowrie's approach in her recent book Die meta-sympotischen Oden und Epoden des Horaz: the fact that the past and the future are entangled in the present, or that the persona loquens speaks to the reader as well as to the addressee, complicates, but does not in the end overshadow sympotic poetry's expression of presence, emblem of a "Poetik des Augenblicks." ${ }^{17}$

The strong and often critical reaction to Heinze's definition of the Horatian ode, in other words, has not succeeded in displacing presence from its central position in the interpretation of the Odes; scholarly discourse has rather, even as it dismisses the interpretive importance of the addressee's presence before the singer in space, given greater emphasis to presence in time, first defining each ode as a discrete moment in a narrative sequence, then seeking to identify a "timeless" present that defies the cruel linear progression of narrative. The territory encompassed by "here and now" has naturally expanded apace. Davis employs the term "scaffolding" to explain how an ode may grow beyond a dramatic occasion yet still embrace an inclusive "now;" Lowrie posits that an "everrecurring present" is enshrined in the text by the rhetorical pose of the speaker,

\footnotetext{
${ }^{15}$ Cf. Lowrie (1997) 49.

${ }^{16}$ Lowrie (1997) 50 and 57-8; cf. also Lowrie (2009b) 7, where the "aesthetics of presence," which identifies song with presence and writing with absence, is defined as "a mystificatory valuation of plenitude in language and the assignment to writing of an irreparable break between composition and reception."

${ }^{17}$ Mindt (2007) 81:" "Schon das sympotische Bild allein also bringt Gegenwart zum Ausdruck, die gesamte sympotische Situation und die Worte ergänzen sich. Eine reine carpe-diem-Lyrik ohne einen konkreten Kontext wäre nur halb so wirksam." In a subsequent discussion of "Gegenwart, Vergangenheit und Zukunft" (81-4), she identifies the symposium, both poetic and actual, as a connecting moment, "verbindendes Moment" (84), a way to integrate past and future into the present.
} 
granting the poet's wish for poetic immortality. Neither scholar adheres to Heinze's strict understanding of notional poetic space, but both desire, as the New Critics did, to fix the Horatian ode in the present, or rather to accommodate the present to the Horatian ode. ${ }^{18}$

In sum, scholars of Horatian lyric today tend to rehabilitate rather than reject Heinze's definition, to loosen Heinze's rigid principles and finesse his straightforward definitions. This tendency points to an abiding desire to capture within a broad conceptual framework some of the collection's most striking features: the poet's carefully observed pretense of orality, his repeated exhortation to enjoy what is at hand, and his stated desire to gain immortality through song. But Davis' and Lowrie's abstractions are nonetheless born of a contradiction. In what sense can the present, the very epitome of the limited and circumscribed, recur or expand without losing its defining singularity? Or, conversely, how can an abstract nunc and a diffuse hic ever truly constitute or capture the fluttering and evanescent moment? The ghostly "temporality of writing" is in one sense, as epitaphs occasionally warn, a cruel fate: you too, $\mathrm{O}$ reader, may soon find your existence reduced to this mere "framework of words," life's insubstantial shadow. ${ }^{19}$ If such a threat feels vital, we may posit that when a point in time and space grows and so gains immortality, it loses something of its essential fragility, something of its beauty and perhaps even something of its desirability. The present in this truest sense does not seem portable or repeatable, but practically invisible and difficult to grasp. Or perhaps impossible to grasp, as Derrida and others have argued: what, after all, is the present but traces of the past, forever waiting to be actualized in the ever-retreating future ${ }^{20}$

${ }^{18}$ For a similar abstraction, cf. Edmunds (2001) 93: "the reader does not have to imagine the addressee as present; it is enough if the addressee is present in the conception of the speaker."

${ }^{19}$ Cf. Frye (1985) 32-3 on the epitaph: "the reader is assumed to be a traveler, pursuing his normal course through time and space, who is suddenly confronted with something he should stop and read. What he reads is the verbal essence of a life which has once had its own context in space and time but is now enclosed in a framework of words. He is often told, at the end, that he has been looking in a mirror: his own context is still in ordinary space and time, but it will eventually disappear, and the verbal essence of his life may make an equally short poem." This is seldom the explicit approach of the epitaphs in $A P$ Book 7, but cf. AP 7.32, where a poet warns passersby of his own sad and empty fate- he still sings from the tomb, but can no longer take his own advice:

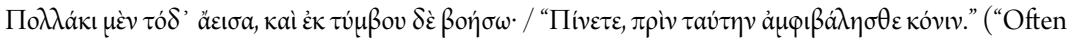
I sang this, but I will cry out even from the tomb: 'Drink, before you embrace this dust.' ")

${ }^{20}$ Lowrie (1997) 49-50 entertains the idea; cf. Derrida (1973) 64-5, 103. Similar ideas are found in Heidegger, e.g. (1996) 321: "The future is not later than the having-been and the havingbeen is not earlier than the present. Temporality temporalizes itself as a future that makes present, in 
The contradiction is played out in an especially vivid and concrete way in the sympotic poems, on which Mindt focuses and to which Davis devotes a chapter. Such poems would seem, as a genre, to be occasional, to necessitate a certain discursive place and time - a pleasant room or a shady spot, with wine and other accoutrements close at hand. Yet in poem after poem, as is his general practice throughout the Odes, Horace is vague about setting and parsimonious with contextual markers that might define explicitly a notional sympotic space, often introducing what seem to be deliberate ambiguities. ${ }^{21}$ The elegant uncertainty of these poems, however contrary to generic expectations, is especially reflected in their frequent commands and directive expressions, which are sufficiently ubiquitous throughout the Odes as to be considered practically characteristic of the poet's technique. ${ }^{22}$ Such expressions offer opposing semantic possibilities. On the one hand, directives may pose as speech, imply immediacy and insist upon the addressee's presence, perhaps dramatic, perhaps merely attentive in some other way to a pressing present concern. On the other hand, they also look toward the future and suggest implicitly that the present will find its true fulfillment only there.

This dual temporality did not escape Heinze's notice: he imagined the speaker of the Odes as physically present before the addressee, but looking toward the future. ${ }^{23}$ A similar idea was previously expressed by the Victorian critic E.S.

the process of having been." Nietzsche's doctrine of eternal recurrence, which imagines a present bound up with the future (Also sprach Zarathustra, "Vom Gesicht und Räthsel” 2: "Und sind nicht solchermaassen fest alle Dinge verknotet, dass dieser Augenblick alle kommenden Dinge nach sich zieht? Also-sich selber noch?"), also anticipates this deconstruction of the present.

${ }^{21}$ For the general point, cf. pp. 2-3 above. Much of the scholarly literature that has arisen around Horace's most celebrated sympotic poems demonstrates just how fraught the question of setting is. Is Plancus in 1.7 in Tibur or abroad (cf. n. 33 below)? Is Thaliarchus in 1.9 at Rome (Fraenkel (1957) 176 entertains the thought) or at some villa closer to Mt. Soracte (cf. West (1967) 3-6 and Syndikus (1972) 117 n. 22)? Is the season fall (Clay (1989)) or winter (Pöschl (1991) 43-4)? Is Maecenas in 1.20 already in the speaker's presence or is the poem an invitation (cf. $\mathrm{n}$. 34 below)? Do poems such as 1.4 and 2.14, which have sympotic elements but do not exhort drinking directly, imply an unspoken displeasure with the host's generosity ( $\mathrm{cf}$. $\mathrm{n} .35$ below)?

${ }^{22}$ Cf. Heinze (1923) 160-2; Nisbet and Hubbard (1970) xxiv-v ("he does not meditate or introspect, but exhorts, questions, invites, consoles, prays, and orders ... As Horace's odes profess to be directed at somebody, they naturally use the techniques of rhetoric."); Barchiesi (2007) 150-1 ("Lyric is poetry that says 'O' ... The prevalent modes of discourse associated with [Horace's] lyric are admonition, persuasion, greeting, farewell, praise and consolation: they all have some relationship to address and are different from soliloquy or epic narrative.").

${ }^{23}$ Heinze (1923) 161: "Aus dem allen ergibt sich, daß der Blick des Lyrikers Horaz stets in die Zukunft gerichtet ist; äußerlich tut sich das schon darin kund, daß das Gedicht so überhäufig mit 
Dallas, who alone among Genette's list of critics identifies lyric not with the present but with the future: ${ }^{24}$

The lyric is an aspiration; its banner has the strange device, Excelsior. It is a prayer for good to come, while it is seen afar like a ship seen by a castaway; or it is the praise of good enjoyed with the assurance that it will last and grow better still; or it is a lament for good flown, with the hope that it may soon return, as birds return in the summer.

As Heinze and others emphasize, the speaker of a Horatian ode does not merely address, but rather prays, exhorts, consoles, advises or announces a decision-directive expressions that go hand in hand with aspiration. Dallas entertains three possible aspirations: hope for the future, hope that the present may continue into the future, and hope that the past will return in the future. Of these three, the most intriguing is the second: for here Dallas suggests that even hope grounded firmly in the present retains its orientation toward the time to come. That the speaker of the Odes on numerous occasions explicitly directs his addressees to privilege the present moment would seem to validate the hoary and imposing critical tradition that assigns the genre of lyric to the present time. Yet the present is only one side of the coin: the same acts of direction, as Dallas and Heinze show, look also toward the future. If Horace deliberately emphasizes such multivalent expressions to hint at presence and setting while maintaining ambiguity of time and place, he would seem to do two contradictory things at once: call attention to the present and illustrate the difficulty of embracing or even identifying it. ${ }^{25}$ If we, conversely, allow such a fragile and fleeting hic et nunc to be abstracted, iterated and expanded, we risk thereby obscuring a crucial nuance of the Odes' complex temporality.

The clearest and simplest way to measure the futurity of the Odes is to examine finite verbs in the future tense, of which there are 180 in the first three books

Imperativ, Konjunctiv der Aufforderung, Futurum beginnt oder schließt."

${ }^{24}$ Dallas (1852) 150. The other critics listed by Genette (cf. n. 6 above) associate lyric with the present, except Staiger, who locates lyric in the past.

${ }^{25}$ Compare Culler (2002) 154 on the apostrophe in Keats' "This Living Hand": "The poem baldly asserts what is false: that a living hand, warm and capable, is being held towards us, that we can see it ... [the poem] knows its apostrophic time and the indirectly invoked presence to be a fiction and says so but enforces it as event." Culler brilliantly captures the paradox of the apostrophic gesture, but ultimately takes the optimistic view that apostrophe makes presence happen. 
alone by my accounting. ${ }^{26}$ Careful analysis of these instances in fact reveals a number of subtleties especially vulnerable to loss by assimilation into an expanded and redefined present. In many cases the future tense is occasioned by caution or gentility, as a politic or polite gesture, and a sizable minority of futures explicitly anticipate or defer to the future an event or action that could plausibly be ongoing. This orientation certainly has significant implications for the interpretation of Horace's political and amatory poetry - some of which have been previously recognized by scholars — but it is probably most relevant to the evolving critical discourse on the sympotic poems, since this group of odes is most closely associated with the "poetics of presence. ${ }^{n 27}$ In these poems, futures are often employed to anticipate or defer focal sympotic events, thereby transforming lyrical aspiration into anxiety about the nature of time. It will be convenient for our purposes to separate finite futures into two rough categories according to their use: those which suggest an order or express a decision (modal or voluntative futures), and those which predict an event or anticipate an outcome (factual futures). ${ }^{28}$

${ }^{26}$ This number is by necessity inexact: I include, for instance, dicam of 1.12 .13 , taking it to be future rather than deliberative subjunctive, but do not count the emendation occupabit (for occupavit of the manuscripts) at 1.12.19, which was offered by Stephanus and printed by Shackleton Bailey. Furthermore, variations of tense are common in the manuscript tradition: e.g inseris for inseres at 1.1.35, dicit for dicet 1.7.9, sumes for sumis at 1.12.2, recinit for recinet at 1.12.3, neglegit for negleget at 3.21 .10 etc. I omit future perfects because, as a related but separate tense, they may well belong in a separate category; I also omit future infinitives and future participles because their temporal qualities are related but arguably different. In the fourth book of Odes, published after an interval of ten years, the poet addresses Augustus directly (cf. Lowrie (2007) 86), speaks of his poetry as written (meis... chartis 4.9.30-31) and in general departs from many of formal pretenses of the first collection (cf. Heinze (1923) 167-8). These new stylistic tendencies certainly merit further study. Nonetheless, as my goal is to explore a discrete corpus of examples in order to establish a basic understanding of the Odes' futurity, I have chosen to limit the scope of this article to simple futures in the first collection.

${ }^{27}$ Ancona (1994), for instance, studies the speaker's attitude toward time in the amatory odes; on 2.5 , she writes that the lover's attempt to control his beloved's temporality fails precisely because of "the pressing movement toward the future" and "postponement of fulfilled desire;" such futurity "places the beloved in a realm that defeats the would-be lover's own attempt to control time" (356).

${ }^{28}$ These categories, it must be noted, do not define a verb's exclusive meaning or use; uses of the future exist on a continuum from strong expressions of will to impartial predictions of expected results. The purpose of categorization here is not to narrow the interpretation of specific examples, to obscure nuance or multiplicity of meaning; the goal is rather to tease out through a close examination of individual cases the various possibilities of the future tense and to examine how this 
Quite a few future verbs appear to act as directives, to imply commands or announce decisions. Roughly $20 \%$ of future verbs in Odes 1-3 may be thus classified (cf. Appendix 1A below). This modal force of the future tense is a reminder of the evolution of the Latin factual future from the Proto-IndoEuropean subjunctive and is also familiar from English-e.g. "you will read this article. ${ }^{29}$ Most direct and closest to these origins are those instances in which a first person future verb announces a decision taken by the speaker of the poem: at 1.18.12-13, for instance, the speaker declares "I will not shake you unwilling, brilliant Bassareus" (non ego te, candide Bassareu / invitum quatiam), imposing his will upon his own actions much as an imperative attempts to influence through the imposition of will the actions of another. Sometimes such forms distinguish themselves from speech acts in the present tense (e.g. "I do") by emphasizing a contrast or a change of heart: thus when the speaker says at 1.26.1-3 "I will hand over sorrow and fear for the violent winds to carry into the Cretan Sea” (tristitiam et metus / tradam protervis in mare Creticum / portare ventis), he perhaps implies a present state of fearful melancholy he intends to leave behind; so too when he threatens that he will not drink unless he hears what lover Megylla's brother has (non alia bibam / mercede 1.27.13-14), we recognize that he intends to put a temporary halt to his celebratory mood while he tries to bring his companions to order. In other cases, a present attitude is projected into the future; the future tense of vetabo at 3.2.26, in the context of the declaration that the man who publishes the mysteries of Ceres will be unwelcome under the speaker's roof (vetabo, qui Cereris sacrum / volgarit arcanae, sub isdem / sit trabibus 26-8), merely underlines emphatically a strongly held belief, true now and forever.

It would be misleading, however, to suggest that a voluntative future is exactly equivalent to a direct command; indeed, commentators often hint that the former adds an element of urbanity and politesse. ${ }^{30}$ This is because the speaker in

tense interacts with and qualifies the present.

${ }^{29}$ Cf. Weiss (2009) 414-15 and the concise formulation of Clackson and Horrocks (2007) 23: "The old PIE subjunctive becomes the Latin future, the old PIE optative becomes the Latin subjunctive." Cf. also Palmer (1954) 271.

${ }^{30}$ Stotlz and Schmalz (1900) 238 explain: "Jedoch wird der Indikativ des Futurs niemals zum Ausdruck eines eigentlichen Befehls gebraucht; dazu dient der Imperativ. Wohl aber spricht derjenige eine Aufforderung im Fut. Ind. aus, welcher sich fein (urban) ausdrücken oder andeuten will, dass er auf die Ausführung sicher rechnet." Thus Nisbet and Hubbard (1970) 204 term it a "polite imperative." Gildersleeve and Lodge (1895) 162, on the other hand, associate this sense of the future with "familiar language," possibly following Kühner (1878) 110. Cf. also Palmer (1954) 307. 
such instances technically omits the command itself-which under certain circumstances might be deemed presumptuous - and, looking toward some future time, politely presumes that the desired outcome may be relied upon. After the speaker of 2.1.9-12, for instance, begs that Pollio not abandon the writing of tragedy for too long (paulum severae musa tragoediae / desit theatris 2.1.9-10), he proceeds to say "you will resume your noble task" (grande munus / repetes), passing over a direct request that Pollio return to the theater, but decorously expecting that such a return is imminent.

The careful and mannered sophistication of this usage suits a poem addressed to a celebrated public figure. But the tactic is apt for other situations as well. At 1.16 .3 , for instance, as the speaker prepares to renounce the angry iambic poetry of his youth, he uses the future pones "you will put" to suggest politely that his former victim do with these violent poems whatever she may wish; the avoidance of a direct command fits his new friendly tone quite elegantly (nunc ego mitibus / mutare quaero tristia 25-6). So too the speaker proceeds gently with Licinius in 2.10, employing the futures vives "you will live" (rectius vives, Licini 1) and contrahes "you will draw in" (contrahes vento nimium secundo / turgida vela 23-4) under the tactful presumption that his addressee will inevitably take his good advice; meanwhile he speaks metaphorically about the risks Licinius has already run. ${ }^{31}$ Likewise, when the speaker at 2.12.10 defers to Maecenas the task of celebrating the wars of Augustus, he uses the future dices "you will say," lest he appear to reject the commission in a preemptory and high-handed fashion.

The so-called "futures of invitation" would also fall into this category, and they too make gentle, urbane and sometimes implicit suggestions rather than insistent demands. When the speaker of 1.17 says to Tyndaris "here in the secluded valley you will avoid the heat of the Dog-star" (17-18), an invitation to leave Rome and come to the country is understood, but the command itself is tactfully suppressed; Tyndaris has another lover, after all. So also with potabis "you will drink" of 1.20.1, the speaker is thought to invite Maecenas to enjoy his Sabine wine, but the suggestion is so modest and discreet that the particulars of the dramatic situation are much disputed. The spirit of invitation is projected into

${ }^{31}$ If Licinius is actually A. Terentius Varro Licinius Murena (cf. Kiessling and Heinze (1955) 202; Syme (1939) 325 n. 5; Nisbet and Hubbard (1978) 152-7), then both the immediate relevance of the advice and its studied vagueness are easily intelligible; this Licinius, brother-in-law of Maecenas by adoption and consular colleague of Augustus in $23 \mathrm{BC}$, was executed the following year for his alleged role in the conspiracy of Fannius Caepio. But the chronology of events presents significant challenges and the identification is disputed by Lyne (1995) 69 n. 8 . 
the indefinite future, at a time unspecified. ${ }^{32}$ Maecenas is under no direct obligation to accept or decline.

Present imperatives and jussive subjunctives may be, as we have seen, understood to enforce presence rather than look to the future. If the voluntative future is viewed as a mere substitute for such unmediated directives, its tense may seem irrelevant. In fact, tense is often critical, especially for the second and third person futures just discussed: it is precisely the future's deferral of immediate obligation that adds sophistication and polite indirection to commands and exhortations. The expectation that the desired action or event will eventually come to pass - if not immediately, then at some appropriate future timerenders a clear request unnecessary and impolitic. By looking toward the moment when a desire will be satisfied, such futures draw attention away from the present, accentuating a temporal orientation already inherent in other directive expressions.

Clearly and self-evidently voluntative futures comprise approximately one fifth of all instances of the future tense in Odes 1-3. In the remainder of cases, the future is less an expression of the speaker's desire or intention and more an ineluctable fact, which will necessarily either continue or depart from some present state of affairs (cf. Appendix 1B below). There is no bright line between voluntative and factual futures: a factual future may hint obliquely at a desire, just as a voluntative future may rely upon its temporality to soften a directive expression. Nonetheless, a difference in emphasis is often evident, especially when a verb in the future tense presents a prediction or a prophecy. Nereus is basically indifferent and objective in 1.15, when he foretells Paris fate using eight verbs in the future tense (repetet ... pectes ... divides ... vitabis ... nosces ... fugies ... proferet ... uret); likewise, when the speaker of an ode is bemoaning deplorable but unavoidable destiny, as the speaker in 2.3 and 2.14 laments the inexorable approach of death, numerous future verbs detail the undesired but inevitably gathering gloom (cedes coemptis saltibus et domo / villaque flavos quam Tiberis lavit, / cedes et exstructis in altum / divitiis potietur heres, 2.3.17-20; nec pietas moram / rugis et instanti senectae / adferet ... erimus ... carebimus ... metuemus ... sequetur ... absumet ... tinget, 2.14.2-4, 12, 13, 16, 24, 25, 27).

Sometimes a prophetic future is contrasted with a verb of another tense. Thus in 1.2 the speaker "has seen" portents (vidimus 13) but the next generation "will

\footnotetext{
32 This is naturally uncharacteristic of an actual invitation, poetic or prosaic. Edmunds (1982) $184-5$ considers neither 1.17 nor 1.20 a true "invitation-poem," since both fail to specify a time.
} 
hear" (audiet 21); thus at 1.4.19-20 young men currently "burn" (calet) for Lycidas but young women will soon grow warm (tepebunt). Thus also at 1.7.1920 the camp "holds" (tenent) Plancus, but Tibur "will hold" him (tenebit), allowing us to understand, it is generally supposed, that Plancus is abroad. ${ }^{33}$ Likewise in 1.20, Maecenas "will drink" (bibes 10) expensive vintages, but such appellations do not "make mild" (temperant 11) the speaker's cups: thus Heinze asserts that Maecenas is at the speaker's house. ${ }^{34}$ Such contrasting futures are, in one sense, natural companions of Davis' "CD [carpe diem] philosophy;" death, inevitable and ineluctable, awaits but remains temporarily distant, providing all the more reason not to let the present moment pass without enjoyment. In the celebrated cases of 1.4 and 2.14, sympotic poems where the speaker makes no explicit request of the addressee, futures in monitory statements such as "soon night will press around you" (iam te premet nox 1.4.16) and "your heir will consume the Caecuban" (absumet heres Caecuba 2.14.25) are thought to have "illocutionary force," that is, to suggest that the host offer more generously from his stores of wine. ${ }^{35}$ This understated mode of expression expands upon the mannered subtlety previously observed in the voluntative future; veiled suggestion and uncertain implication are often preferable to the direct imposition of will.

A future verb may also generalize or indicate the continuance of a present state of affairs into a future time. Amabo ("I will love") of 1.22.22, for instance, asserts that the speaker will continue to love Lalage regardless of time or place. The contrast here is not between two different actions, but between two times and places, with the continuance of the speaker's love in the extreme conditions of the

${ }^{33}$ Moles (2002) 90, for instance, a recent exponent of this traditional interpretation, sets the poem in a symposium on the eve of Plancus' desertion of Antony in 32, just before Plancus returned to Rome. Eminent dissenters who argue that the poem's setting is in fact Tibur include Syme (1963) 511, Quinn (1980) 135 and Lyne (1995) 84.

${ }^{34}$ Nisbet and Hubbard, Kiessling and Heinze, Quinn et al. take bibes to mean "you will drink (at your house, but not at mine)." This does seem the most plausible interpretation, although if potabis in line 1 is taken to mean the opposite, i.e. "you will drink (at my house)," the change in supposed location falls rather heavily on the emphatic tu. Emendations to the subjunctive have been suggested (liques [Krüger, Müller], bibas [Keller]) or to the present indicative: bibis (a reading of the Cod. Voss. et alii, according to Peerlkamp, but unmetrical), vides (Eckstein, Munro), moves (Bücheler), liquas (Delz).

${ }^{35}$ Cf. Davis (1991) 160-1: “... in the context of CD [i.e. carpe diem] poetry it is often the case that declarative sentences, especially when projected into the future, have the illocutionary force of exhortations." 
hypothetical future representing the depth of his present affection. The "gnomic" future has much the same nuance: futurity here gives a statement the sanction of eternity, strengthening a present truth by mirroring it in a contrasting time. Thus we are told at 3.1.17-21 that for the man over whom the sword of Damocles "will hang" (pendet), Sicilian feasts "will not elaborate" (elaborabunt) sweet taste, and music "will not bring back" (reducent) sleep. The future situation is hypothetical, but it illustrates an ever-present truth.

Different but to a certain degree coextensive is the use of the future in questions and conditions, where the speaker may not illustrate a present truth or confidently predict an outcome, but rather seems to contemplate a possible event and perhaps its likely consequence. Orthodox Latin grammar dictates that a condition with a future in the apodosis should have a coordinating future or future perfect in the protasis, rather than the anticipatory present common in English. ${ }^{36}$ The temporality of the Latin usage may indeed seem unnecessarily precise to the English ear. So at 2.14.11-12, the waters of the Styx must be crossed, "whether we will be kings or poor farmers" (enaviganda sive reges / sive inopes erimus coloni); the tense of erimus in the protasis is drawn to the futurity of the gerundive in the apodosis. But a future even in a condition usually makes a distinct point. Although our wealth and social station are relevant at the time of speaking, they will be all the more affecting at the future moment when we are poised to lose our possessions in death. The just man described at 3.3.1-8 is unshakeable: "if the shattered world should fall upon him, the ruins will strike him unafraid" (si fractus illabatur orbis / impavidum ferient ruinae 3.3.7-8). The ruin of the world is an unlikely supposition; the just man's fearlessness is a certainty. ${ }^{37}$ In other cases, the speaker wonders aloud, often rhetorically, whether or how some expectation will be fulfilled. In 1.2, a disastrous flood threatens Rome: whom will Jupiter choose as a savior? (cui dabit partis scelus expiandi / Iuppiter? 1.2.29-30). Such futures are not really prophetic - they are not always sure of the outcome-nor do they invariably generalize or expect the present to continue - the situation they contemplate may be quite specific or extraordinary. They tend to look toward the future with more uncertainty than confidence.

\footnotetext{
${ }^{36}$ The classical preference for conditions with a future in both clauses (cf. Stolz and Schmalz (1900) 412) probably secures the future inseres at 1.1 .35 as well as quaeret at 3.24 .26 , but the variants inseris and quaerit, which occur in a number of manuscripts, hint that this is hardly an ironclad rule; Horace also employs present-future conditions, as at Odes 4.1.9-12 (tempestivius in domum / Pauli purpureis ales oloribus / comissabere Maximi, / si torrere iecur quaeris idoneum).

${ }^{37}$ Cf. Nisbet and Rudd (2007) 40.
} 
Futures that disguise imperatives, those that prophesy and those that illustrate a continuing or eternal truth may all be understood as foils, as mirrors set against some notional present but positioned to reflect light back upon it. The action of these verbs does not, of course, take place in the hic et nunc, but perhaps their futurity merely balances out one side of the "pivot" of which Lowrie speaks, an illustration of the inside by the illumination of the outside. The darker the shadow of death, so the argument goes, the sharper our appreciation of life. This is a tidy theory, but it has the same shortcomings as Heinze's definition of the Horatian ode: it requires that the reader read a basic premise into poems where that premise is not self-evident. ${ }^{38}$ Of course the future does often serve to emphasize the present, as Davis and others effectively show, but it hardly follows that the tense must invariably perform only this function. The sheer preponderance of futures throughout Odes 1-3 broadly suggests an alternative interpretation: that the attention of both the reader and the poet may be surreptitiously drawn away from the present by a powerful and countervailing temporal force.

The supposition that futurity may in fact question and destabilize the present is confirmed by a close analysis of individual instances. There are numerous verbs in the future tense through which the speaker's attention shifts emphatically from a constructed present to some expectation as yet unfulfilled, which the poem is consigned merely to await. Many voluntative and monitory futures, as we have shown, seem calculated to defer rather than seize upon, or obscure rather than accentuate, some present obligation or concern. Futures in conditions or questions sometimes take this a step further: they may openly ponder, as in a dream, what events and consequences are possible in the time to come. It is often desirable for a poem to delay or postpone certain focal events; indeed, the

${ }^{38}$ Davis (1991), for instance, makes a similar argument in regard to the convivial odes, proceeding by a number of steps. He first posits that "Horatian lyric discourse typically 'argues' a coherent nexus of ideas through nuanced variations in form and presentation" (3); this includes a "rhetorical schema" for the "carpe diem ode" (45). The components of this schema not found in individual convivial poems may be understood to pertain even though left implicit, because the poet in these cases relies on "the reader's prior awareness of the CD structure" (145). The culmination of the schema is a "prescription" such as rapiamus, amici / occasionem de die (Epod. 13.3-4). Contrary elements are foils for this central argument. "The sympotic gesture that crowns that structure is counterpoised to the ineluctable circumstance of human mortality ... the presence of death, as a recurrent motif, in the very bosom of the Horatian convivium is not indicative ... of a gloomy disposition ... but, on the contrary, of an intense recommitment to the joys of the present" (147-8). 
speaker may, through strategic employment of the future tense, anticipate poetic acts and aesthetic decisions (a Pindaric usage), moderate or evade praise of great men, especially Augustus, or even add urgency and suspense to sympotic poems - the very odes thought to be paradigmatic of Horace's "poetics of presence." ${ }^{39}$

Consider, first of all, the mystifying and much disputed future tense of inseres ("you will insert"), which figures prominently in the epilogue to Odes 1.1. The future here is generally understood to postpone the judgment of the quality of the Odes until the whole collection may be read: neither Maecenas nor any other reader will render such a decision until this indefinite future time. ${ }^{40}$ The idea is expressed concisely and cleverly, and, as Sutherland has pointed out, implicates the reader in the same breath as Maecenas; it also expands the time of reading to encompass an extra-poetical future, embracing not just this poem but the whole collection, and the actions and judgments of all readers yet to come. ${ }^{41}$ Instead of projecting himself into the "iterative" present of the abstract reader, as Ovid does, for instance, Horace pushes the valorizing moment of judgment into the uncertain future. ${ }^{42}$

This challenging concept has unsettled enough readers of Horace to raise the specter of a textual controversy. The present inseris appears in a significant minority of manuscripts, and scholars such as Peerlkamp, Hermann and now Shackleton Bailey have suggested various solutions and simplifications. ${ }^{43}$ Yet

\footnotetext{
${ }^{39} \mathrm{I}$ have collected all such instances in Appendix II, marking each according their previous categorization as factual or voluntative.

${ }^{40}$ Cf. Nisbet and Hubbard (1970) 15: "Here he pretends that Maecenas has still to read the collection."

${ }^{41}$ This possible broader meaning of inseres is expressed differently by different scholars. Pomeroy (1980) 37 states "the wish expressed by inseres is no longer confined to the stated addressee, but can be taken as the ideal second person singular of the future." Gold (1992) 176 argues that the subject of inseres could be "the Muses and the gods referred to in the previous lines and posterity;" Sutherland (2002) 31 thinks the reader may become "assimilated to the ode's addressee, who is implied in the second-singular form of inseres." Kovacs (2010) 308-9 argues that the subject of inseres is an "indefinite second person."

${ }^{42} \mathrm{Cf}$. Ovid, Tr. 4.10.131-32, which is focalized from the reader's perspective: sive favore tuli, sive hanc ego carmine famam, / iure tibi grates, candide lector, ago. "Whether I earned this fame by favor or by song, I give thanks, rightly, to you, fair reader.")

${ }^{43}$ Peerlkamp (1834) 8 reads the variant inseris, but obelizes the whole of line 36 , on the grounds that Horace would not brag about what he has not yet accomplished: sed hoc statim, initio rei susceptae, de se praedicare, est hominis superbi. Hermann (1877) 395-404 argues for the excision of the first two and last two lines. Shackleton Bailey (2001) 2 thinks that the text of lines 32-6 is
} 
there are other cases in which the speaker anticipates some future song of praise or contemplates, as he sings, what the subject of his song will be. The litany of futures in 1.12 portrays a song of praise as imminent when it is manifestly ongoing; in 3.25 dicam ("I will say" 7) and loquar ("I will speak" 18) likewise anticipate a remarkable poem rather than acknowledge that such a poem has already begun. ${ }^{44}$

In a few instances, the poet uses the future tense to postpone his most extravagant praise of Augustus: in 1.2, for example, dabit ("will give" 29) suggests that Jupiter has not yet chosen a savior of Rome, even though the final stanzas imply that such a savior is already at hand. In 3.3 (Iustum et tenacem) Augustus "will drink" (bibet 12) nectar among the gods-although he was implied to be a god in human form at 1.2.41-52 - and in 3.5 the emperor "will be considered" (habebitur 2) a god on earth, but only after he subdues the Britons and the Persians. In 3.24, an anonymous savior-whoever "will wish" (volet 25) to end civil unrest - is implored to be bold enough to rein in untamed license, if he "will seek" (quaeret 27) that the title pater be inscribed on statues ${ }^{45}$-as if Augustus has not yet taken up the issue of civil strife or sought recognition. ${ }^{46}$ The future

corrupt, although he does not actually print any changes to the received text (text. recept. quem pro corrupto habeo, tamen reliqui); his suggestion, taken from Bergk, proposes to punctuate after secernunt populo and start a new sentence as follows (changes underlined): si neque tibias/ Euterpe cohibet nec Polyhymnia/ Lesbois refugit tendere barbiton/ chordis, me lyricis vatibus inserens/ sublimi feriam sidera vertice. The reason for the disappearance of the second person (given in Shackleton Bailey (1985) 153) is that the approval of Maecenas (i.e. the "you" of inseres) ought not to take precedence over the approval of the Muse.

${ }^{44}$ The usage has a parallel in Pindar, who often uses a first person future to announce a song and to create the fictional impression that it is being composed on the spot, as Pfeiffer (1999) 33-43 shows; in $0.2 .2-6$, the inspiration for Odes 1.12.1-3, Pindar immediately answers the question

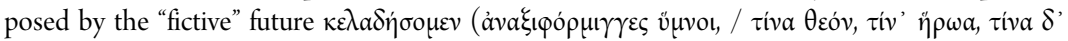

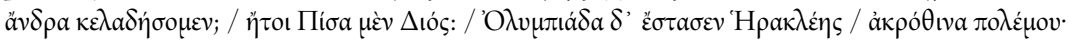

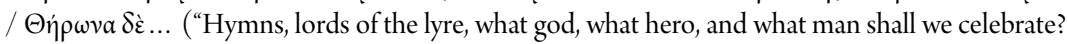
Surely Pisa belongs to Zeus, and Heracles founded the Olympic games as spoils from war; and Theron ...")). Horace, conversely, maintains the sense of anticipation and futurity until the very end in order to defer direct address and unambiguous praise of Augustus.

${ }^{45}$ What exactly is to be inscribed on the statues is contested; cf. Kiessling and Heinze (1955) 354 and Nisbet and Rudd (2004) 283. But is unlikely to be pater urbium: pater is normally constructed with the singular urbis (Ov. Fast. 3.72; Man. 4.718; Stat. Silv. 1.4.95, 4.8.20; Juv. 2.126; cf. Woodman and Martin (1996) $228 \mathrm{n}$. 1) and this formulation is universal enough that the Greek

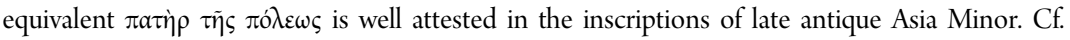
Roueché (1979).

${ }^{46}$ Cf. Nisbet and Rudd (2004) 282: "the future volet avoids the suggestion that the issue [of civil 
functions ably as an adjunct to discretion both in recusatio and panegyric; promises ('I shall sing later'), concessions ('someone else will sing') and conditions ('I shall sing if ...') all lessen the injury of refusal. So too does this same deference and delay play a critical role in sympotic poems. Here the future tense often serves to underline the characteristic and powerful mode of aspiration, questioning the transcendence of the present moment and conveying anxiety about the relentless passage of time.

In 2.5.9-10, the speaker advises an anxious lover to delay the gratification of his desire (tolle cupidinem / inmitis uvae "put an end to desire for the unripe grape"), a sentiment which contrasts sharply with insistent erotic overtures in this and other poems. ${ }^{47}$ Such an approach to pleasure more broadly understood, however, is not unparalleled in Horace's sympotic poetry; verbs in the future tense also occasionally locate gratification outside of the poem, even when this postponement seems at odds with the dramatic setting of the symposium. Consider the final two stanzas of 2.7 , which unfold after the speaker has welcomed his friend Pompeius home from war and proposed a feast (21-8):

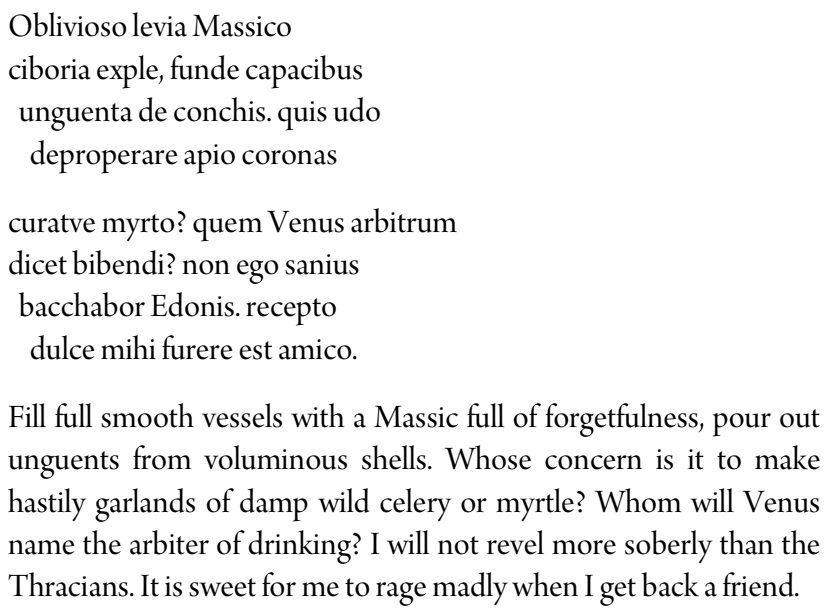

Fill full smooth vessels with a Massic full of forgetfulness, pour out unguents from voluminous shells. Whose concern is it to make hastily garlands of damp wild celery or myrtle? Whom will Venus name the arbiter of drinking? I will not revel more soberly than the Thracians. It is sweet for me to rage madly when I get back a friend.

The imperatives exple and funde order directly that preparations be made; the present curat inquires after the distribution of responsibilities. If the former imply that preparations are underway, the latter suggests anxiety that they are not

strife] is a current one." On the future of quaeret, cf. n. 36 above. The whole stanza is studiously vague: cf. Fraenkel (1957) 242; Williams (1969) 127; Quinn (1980) 284; Oliensis (1998) 128.

${ }^{47}$ E.g. Odes 1.23.11-12: tandem desine matrem / tempestiva sequi viro. ("cease at last to follow your mother, when you are ready for a man.") 
proceeding quickly enough. The futures dicet and bacchabor, therefore, find the speaker anticipating the moment of celebration-not far off, but not yet at hand-as if it were a pleasant daydream. A similar transition from present to future is evident in 2.11, where the speaker proposes an impromptu celebration (13-22):

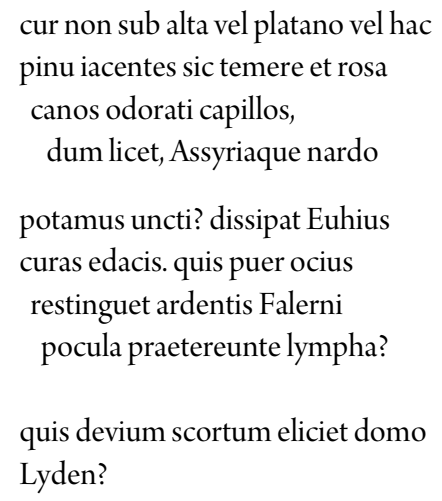

Why do we not drink lying thus without further ado either under the tall plane tree or this pine, white hair perfumed with the rose, while it is allowed, and anointed with Assyrian nard? The wine god scatters gnawing cares. Which boy will quench swifter the cups of burning Falernian with the water passing by? Who will lure forth Lyde, that whore in hiding, from her home?

The speaker begins the poem in the present, with regret that a political discussion has distracted from a potential drinking bout: why delay, when the salutary effects of wine are available now? Then thoughts turn to the immediate future; which slave will mix the wine faster? The next sentence finds the speaker plunging deeper into a reverie of impending frivolity: who will be able to lure Lyde out of hiding? The poem concludes with a wistful description, couched in an order, of Lyde coming forth with her ivory lyre, hair neatly bound up in the Laconian manner. The sympotic consolation is not, in fact, immediately accessible: preparations must first be made, and burgeoning desire for the moment deferred.

There are further examples of this ambiguous temporality. The speaker of 3.8 is surprised by Maecenas in the midst of his preparations for the Matronalia but, in a shift of temporal emphasis, the celebration itself is merely anticipated (912): 
hic dies anno redeunte festus corticem adstrictum pice dimovebit amphorae fumum bibere institutae consule Tullo.

This holiday, as the year returns to it, will remove the pitch-smeared cork of a wine-jar that first began to drink in the smoke in the consulship of Tullus.

For the moment the amphora remains corked, within reach, perhaps, but as yet untouched. In 3.14, the speaker declares that the day of Augustus' arrival from Spain "will drive away" (exiget 14) dark thoughts and that he "will not fear" (metuam 15) a violent death - but this moment of clarity is only anticipated, not yet experienced. Most emphatic of all are Odes 3.13 and 3.17, which explicitly procrastinate, putting off until the next day an absolutely focal event - in the first instance a sacrifice, in the second a party for which the speaker enjoins Aelius Lamia to prepare.

Davis is not without an answer for this particular problem. He writes of 3.17: "the lyrist has not, we may safely assume, relinquished his cherished view that the present, rather than the future, should be the dominant focus of human concern. On the contrary, the concrete response that he urges - the piling on of firewood - is indeed to be implemented at once, for both storm and antidotal banquet are imminent." ${ }^{38}$ The immediate future may on this view be treated as synonymous with the present. A dogma of Bundy is sometimes cited for the same purpose, that is, in order to remove the nagging temporality of a verb in the future tense. Bundy writes, in reference to the future $\kappa \mathcal{\varepsilon} \lambda \alpha \delta \dot{\eta} \sigma \omega$ at Olympian 11.14, that the first person future indicative in Pindar "never points beyond the ode itself, and its promise is often fulfilled by the mere pronunciation of the word." ${ }^{49}$

But just as this idea has now been carefully examined and refuted by Pfeijffer, who concludes that no first person future in Pindar can be separated from its tense without a loss of meaning ${ }^{50}$ — so too we would do well to wonder if it is

\footnotetext{
${ }^{48}$ Davis (1991) 154.

${ }^{49}$ Bundy (1969) 21; cf. also Faraone (1995), who finds similar futures in Greek magical texts and in Theocritus' second Idyll. Nisbet and Rudd (2004) 298 cite Bundy in order to elucidate audiar at 3.25.4.

${ }^{50}$ Pfeijffer (1999) 67. He divides all first person futures in Pindar into two categories: I) those referring to some point in the poem or the poem itself and II) those referring to a general thought or some point beyond the poem. With the exception of generalizing or gnomic futures, Pindar's first person futures generally convey the speaker's intentions and so would usually fall into our first
} 
really Horace's goal to focus so exclusively on the present, or whether he might have something more subtle in mind. The imperative, after all, is already poised between the two tenses: it both expects the attentive presence of the addressee and points to an event not yet occurred, a wish not yet fulfilled. The use of the future to illustrate the present by contrast is subject to a similar interpretation: even as these verbs draw attention to the present, they undermine its singularity and transcendence, illustrating the impossibility of extricating the present moment from time yet to come. The futures that defer aesthetic decisions, delay excessive panegyric, and postpone sympotic acts merely deploy lyric's familiar mode of aspiration to sharpen anticipation or soften disappointment. In some cases, as in 3.13 and 3.17, the poet accedes entirely to the allure of anticipation, putting off the symposium itself.

In fact, what these last two remarkable poems make inescapably evident is the overwhelming tendency of the sympotic odes to be situated at a moment of transition, exhorting or anticipating some climactic event, anxious that it will never come, that time is moving too quickly. And this anxiety over the all-tooswift passage of time may even entertain the thought that there is no present moment as such, but only the future constantly and imperceptibly becoming the past. ${ }^{51}$ The expression carpe diem itself conveys much this same paradox: not seize the day, but rather endeavor to pluck some of time's fruits or flowers as the whole grows, like a vine, forever out of reach..$^{52}$ Bundy's and Davis' assimilation of troublesome futures to the present could therefore be turned around, in the manner of Derrida, and taken rather to undermine and question the present, to

category of voluntative futures. Yet Pfeiffer takes pains to emphasize the importance of each verb's temporality, an approach which is consonant with the conclusions of this study; cf. Pfeijffer (1999) 14 n. 21.

${ }^{51}$ Traina (1973) 21 anticipates this idea by emphasizing the shadow always cast by the future on the present as well as the defensive and fearful posture assumed by the speaker of carpe diem: "Il presente oraziano, l'abbiamo visto, è sempre in rapporto antitetico con l'idea del futuro, come due facce della stessa medaglia: una fuga dal domani, che sull'oggi proietta un'ombra di morte ... saggezza di difesa, e, in fondo, rinuncia: mitte sectari, rosa quo loquorum / sera morteur ..."

${ }^{52}$ So originally Porphyrio ad loc: translatio autem a pomis sumpta est, quae scilicet ideo carpimus, ut fruamur. Cf. West (1967) 58-64, Traina (1973), Barchiesi (2007) 154; compare volucris dies, 3.28.6, 4.13.16. In Horace, humans may either take some part from the day or the hour (rapiamus, amici, / occasionem de die (Epod. 13.3-4), partem solido demere de die (Odes 1.1.20)) or accept the gifts of time (dona praesentis cape laetus horae (Odes 3.8.27), tu quamcumque deus tibi fortunaverit horam / grata sume manu (Epist. 11.22-3)); as Traina (1973) 16 shows, the dies of carpe diem is to be plucked from the invida aetas of 1.11.7, which itself flees irresistibly away. 
reveal its inadequacy. ${ }^{53}$ To understand the present deeply and truly is to understand that it is always anticipation, never actualization, always becoming, never being. It is but a vanishing moment of brilliance ever pursued and ever fading from that inexpressible horizon where the world of the poem meets the world of experience.

Horace does on occasion produce a sympotic poem where presence in every sense plays a central role. Odes 1.27, for instance, clearly dramatizes an on-going scene and depicts the speaker reacting to events occurring around him. The evident confluence of temporal and spatial presence in the setting of this poem, however, is the exception that proves the rule. Thus the relentless emphasis in critical discourse on identifying and defining presence often obscures a crucial point: just as the poet rarely fixes "here" in space with absolute certainty, he seldom represents "now" in time as discrete, singular and preserved by the text itself. Far more often, the speaker suggests presence, orders it, exhorts it and implies that it is imminent, all the while pushing it just beyond the poem, dramatizing instead the anxiety of waiting, the difficulty of fully embracing the elusive moment and the inevitable weakness of will. A poem already mentioned-Odes 3.14 - illustrates this fear of time's continuity in a particularly elegant way. The speaker orders a celebration of Augustus' arrival from Spain (prodeat 6, parcite 12); he expects that the day will drive away (exiget 14) his cares, nor will he fear strife and a violent death (nec tumultum / nec mori per vim metuam 14-15). Before these orders and expectations are realized, however, the setting shifts to a private symposium anticipated through imperatives (i pete unguentum 17, dic et ... properet 21). The constitution of this event remains uncertain; the speaker asks a slave to summon clear-voiced Neaera, but will not incite an altercation if her doorman stands in the way. Move on (abito 24), he implores, aware that time is passing too quickly. ${ }^{54}$ The mode of anticipation flows irresistibly forward, bearing with it the flotsam of the past: the wine, elixir of forgetfulness, remembers the Social War (cadum Marsi memorem duelli 18) and the speaker, even as he awaits the dissipation of cares, reflects back upon the painful consulship of Plancus. ${ }^{55}$ The poem captures the drama and urgency of an

\footnotetext{
${ }^{53}$ Cf. n. 20 above.

${ }^{54}$ The future imperative abito appropriately keeps the focus on the hypothetical future.

${ }^{55}$ Cf. Fraenkel (1957) 290 and Oliensis (1998) 148-9: "But the wine for which Horace calls in Odes 3.14, stained as it is by both the Social War and the rising of Spartacus, seems peculiarly illchosen ... It is the day of Caesar's return which will 'banish black cares' ... and Horace's wine which brings care back into the picture." Others, e.g. Syndikus (1973) 152, believe that the civil wars are
} 
event that will never come, yet is forever becoming, forever inextricable from what has been.

Futurity is an unavoidable quality of the Horatian ode: most odes, in one way or another, look hopefully or despondently toward the future. This prevailing attitude is in one sense a natural result of poetry that begs, prays, curses, advises or consoles, but the usage is also distinctly shaped by sophisticated ethical and aesthetic sensibilities. Futurity deepens the shadows of discretion and qualification that fall over much of Horace's poetic discourse with the eminent men of his day, and especially over his praise of Augustus. A thrilling note of spontaneity and incompletion sounds when the speaker of an ode announces and anticipates a future song. Likewise, in the sympotic odes, a genre traditionally associated with immediacy of situation and setting, the speaker's constant gaze toward the retreating horizon of time imparts a curiously vivid timelessnessbut through paradoxical means, through the problematization of presence, rather than presence itself. The speaker's plight is, in other words, not unlike that of the lover on Keats' Grecian urn (Ode on a Grecian Urn, 17-19):

Bold Lover, never, never canst thou kiss

Though winning near the goal- - yet do not grieve

She cannot fade, though thou hast not thy bliss ...

The symposium that is, like this kiss, forever unrealized also never perishes. That thought, however, is not without sorrow for the aspirant: Horace characteristically tempers expectation with the fear that the past is inescapable, the future forever retreating, the present impossible to embrace fully. If the poet gains thereby a measure of immortality, he does so not only by inscribing himself into the text, but also by joining his moment to that sempiternal stream of becoming which runs always toward the future - a future neither closer to nor further from the reader than the poet.

DANIEL BARBER

Middlesex School,dbarber@mxschool.edu

here remembered only to emphasize the present prosperity by contrast and to remind the reader that this prosperity depends on Augustus alone. For the identification of consule Planco with the year of Philippi, cf. Klingner (1965) 395-405. 
Appendix I: Uses of the Future Indicative in Odes 1-3:

\section{$\underline{\text { A. Voluntative Futures }}$}

1. Announcing an intention or decision:

\begin{tabular}{|c|c|}
\hline Ode & Future verb (line number) \\
\hline 1.10 & canam (5) \\
\hline 1.12 & ricam (13), silebo (21), dicam (25),referam (39) \\
\hline 1.18 & tradam (2) \\
\hline 1.26 & bibam (13) \\
\hline 1.27 & bacchabor (27) \\
\hline 2.7 & feriemus (32) \\
\hline 2.17 & vetabo (26) \\
\hline 3.2 & redonabo (33) \\
\hline 3.3 & erit (19) \\
\hline 3.10 & feriam (43), tenebo (44) \\
\hline 3.11 & habebit (4) \\
\hline 3.26 & timebo (7), suscitabo $(8)$ \\
\hline 3.27 &
\end{tabular}

2. Jussive or hortatory:

\begin{tabular}{|c|c|}
\hline Ode & Future verb (line number) \\
\hline 1.6 & scriberis (1) \\
\hline 1.7 & ibimus (26), iterabimus (30) \\
\hline 1.12 & regnes (52) \\
\hline 1.12 & quaties (58), mittes (59) \\
\hline 1.16 & voles (2), pones (3) \\
\hline 1.19 & veniet (16) \\
\hline 1.21 & aget (16) \\
\hline 2.1 & repetes (12) \\
\hline 2.2 & regnes (9) \\
\hline 2.6 & sparges (23) \\
\hline 2.10 & vives (1), contrahes (23) \\
\hline 2.12 & dices (10) \\
\hline 3.28 & cantabimus (9), recines $(11)$, dicetur $(15)$ \\
\hline
\end{tabular}

3. Concessive:

\begin{tabular}{|c|c|}
\hline Ode & Future verb (line number) \\
\hline 1.7 & laudabunt (1), dicet (9) \\
\hline 1.12 & reget (56) \\
\hline 1.20 & bibes (10) \\
\hline
\end{tabular}

4. Invitation

\begin{tabular}{|c|c|}
\hline Ode & Future verb (line number) \\
\hline 1.17 & manabit (15), vitabis (18), dices (19), duces (22), confundet (23), metues (24) \\
\hline 1.20 & potabis (1) \\
\hline
\end{tabular}


$\underline{\text { B. Factual Futures }}$

1. Prophesying or making a prediction:

\begin{tabular}{|c|c|}
\hline Ode & Future verb (line number) \\
\hline 1.2 & audiet (21) \\
\hline 1.4 & premet (16), sortiere (18), mirabere (19), tepebunt (20) \\
\hline 1.5 & flebit (7), emirabitur (8) \\
\hline 1.13 & solvet (20) \\
\hline 1.14 & referent (1) \\
\hline 1.15 & $\begin{array}{l}\text { repetet (5), pectes (14), divides (15), vitabis (18), nosces (27), } \\
\text { fugies (31), proferet (33), uret (35) }\end{array}$ \\
\hline 1.25 & flebis $(10)$, saeviet $(15)$ \\
\hline 1.28 & linquar (33), resolvent (34) \\
\hline 1.36 & deponent (18), divelletur (19) \\
\hline 2.2 & $\operatorname{vivet}(5)$, aget $(7)$ \\
\hline 2.3 & cedes (17), cedes (19), potietur (20) \\
\hline 2.5 & distinguet (11), sequetur (13), apponet (15), petet (16) \\
\hline 2.10 & erit (18) \\
\hline 2.14 & $\begin{array}{c}\text { adferet (4), carebimus (13), metuemus (16), sequetur (24), } \\
\text { absumet (25), tinget (27) }\end{array}$ \\
\hline 2.15 & relinquent (2), visentur (4), evincet (5), spargent (7), excludet (10) \\
\hline 2.17 & ducet (9), ibimus, ibimus (10), divellet (15) \\
\hline 2.20 & $\begin{array}{l}\text { ferar (1), morabor (3), relinquam (5), obibo (7), cohibebor (8), } \\
\text { visam (14), noscent (19), discet (20) }\end{array}$ \\
\hline 3.3 & bibet (12), iterabitur (62) \\
\hline 3.5 & habebitur (2) \\
\hline 3.7 & restituent (2) \\
\hline 3.8 & dimovebit (10) \\
\hline 3.13 & donaberis (3), inficiet, (5) fies (13) \\
\hline 3.14 & exiget (14), metuam (15) \\
\hline 3.17 & sternet (12), curabis (15) \\
\hline 3.20 & fugies (3) \\
\hline 3.21 & negleget (10), aderit (21), producent (23) \\
\hline 3.23 & sentiet (5), tinget (6) \\
\hline 3.24 & expedies (8) \\
\hline 3.27 & $\operatorname{reddet}(71), \operatorname{ducet}(72)$ \\
\hline 3.29 & efficiet (46), diffinget (47), reddet (47) \\
\hline 3.30 & moriar (6), vitabit $(7), \operatorname{crescam}(8)$, dicar $(10)$ \\
\hline
\end{tabular}

2. Generalizing or continuing a present state of affairs into the future:

\begin{tabular}{|c|c|}
\hline Ode & Future verb (line number) \\
\hline 1.7 & tenebit $(20)$, ferret $(25)$ \\
\hline 1.9 & dabit $(14)$ \\
\hline
\end{tabular}


DANIEL BARBER

\begin{tabular}{|c|c|}
\hline 1.11 & erit (3) \\
\hline 1.22 & amabo (22) \\
\hline 1.27 & poterit (22), expediet (24) \\
\hline 1.28 & minabitur (25), licebit (35) \\
\hline 2.16 & porriget (32) \\
\hline 3.1 & pendet (18), elaborabunt (19), reducent (21) \\
\hline 3.4 & eritis (29), temptabo (31), visam (33), visam (35), convenient (69) \\
\hline 3.5 & redibit (26), erit (32) \\
\hline 3.6 & lues (1) \\
\hline 3.16 & feret (22), porrigam (39) \\
\hline
\end{tabular}

3. Contemplating a potential outcome:

\begin{tabular}{|c|c|}
\hline Ode & Future verb (line number) \\
\hline 1.1 & inseres (35),feriam (36) \\
\hline 1.2 & dabit (29) \\
\hline 1.12 & recinet (3) \\
\hline 1.24 & inveniet (8) \\
\hline 1.29 & serviet (6), statuetur (8), neget (10) \\
\hline 1.33 & iungentur (8) \\
\hline 2.11 & restinguet (19), eliciet (21) \\
\hline 2.14 & erimus (12) \\
\hline 3.3 & ferient (8) \\
\hline 3.9 & metuam (11), parcent (12), patiar (15), parcent (16) \\
\hline 3.14 & fiet (24) \\
\hline 3.24 & volet (25), quaeret (27) \\
\hline 3.25 & audiar (4), dicam (7), loquar (18) \\
\hline
\end{tabular}

Appendix II: Anticipatory Futures in Specific Contexts

Anticipating an aesthetic decision or poetic act:

\begin{tabular}{|c|c|c|}
\hline Ode & Future verb (line number) & Location in Appendix I \\
\hline 1.1 & inseres (35), feriam (36) & $\mathrm{B} 3$ \\
\hline 1.2 & dabit (29) & $\mathrm{B} 3$ \\
\hline 1.10 & canam (5) & $\mathrm{A} 1$ \\
\hline 1.12 & recinet (3), dicam (13), silebo (21), dicam (25), & $\mathrm{A} 1: 13,21,25,39$ \\
& referam (39) & $\mathrm{B} 3: 3$ \\
\hline 3.4 & convenient (69) & $\mathrm{B} 2$ \\
\hline 3.28 & cantabimus (9), recines (11), dicetur (15) \\
\hline
\end{tabular}

Anticipating praise of Augustus:

\begin{tabular}{|c|c|c|}
\hline Ode & Future verb (line number) & Location in Appendix I \\
\hline 3.3 & bibet (12) & B1 \\
\hline 3.5 & habebitur (2) & B1 \\
\hline 3.24 & volet (25), quaeret (27) & B3 \\
\hline
\end{tabular}




\begin{tabular}{|l|l|c|}
\hline 3.25 & audiar (4), dicam (7), loquar (18) & B3 \\
\hline
\end{tabular}

Anticipating sympotic acts and pleasures:

\begin{tabular}{|c|c|c|}
\hline Ode & Future verb (line number) & Location in Appendix I \\
\hline 1.36 & deponent (18), divelletur (19) & B1 \\
\hline 2.7 & bacchabor $(27)$ & A1 \\
\hline 2.11 & restinguet $(19)$, eliciet $(21)$ & B3 \\
\hline 3.8 & dimovebit $(10)$ & B1 \\
\hline 3.14 & exiget $(14)$, metuam $(15)$ & B1 \\
\hline 3.21 & negleget (10), aderit (21), producent (23) & . \\
\hline
\end{tabular}

Anticipating the celebration as a whole:

\begin{tabular}{|c|c|c|}
\hline Ode & Future verb (line number) & Location in Appendix I \\
\hline 3.13 & donaberis (3), inficiet, (5) fies (13) & B1 \\
\hline 3.17 & sternet (12), curabis (15) & B1 \\
\hline
\end{tabular}

\section{WORKS CITED}

Ancona, Ronnie. 1994. Time and the Erotic in Horace's Odes. Durham, NC.

Barchiesi, Alessandro. 2007. "Carmina: Odes and Carmen Saeculare." In Cambridge Companion to Horace, edited by S.J. Harrison, pp. 144-61. Cambridge.

Bundy, Elroy R. 1969. Studia Pindarica I. Berkeley, CA.

Citroni, Mario. 1995. Poesia e lettori in Roma antica: forma della communicazione letteraria. Rome.

Clackson, James and Geoffrey Horrocks. 2007.The Blackwell History of the Latin Language. Malden, MA.

Clay, Jenny Strauss. 1989. “Odes 1.9: Horace’s September Song.” CW 83: 102-105.

Culler, Jonathan. 1985. "Changes in the Study of Lyric." In Lyric Poetry: Beyond New Criticism, edited by C. Hošek and P. Parker, pp. 38-54. Ithaca, NY.

__ 2002. The Pursuit of Signs: Semiotics, Literature, Deconstruction. 2nd edition. Ithaca, NY. Originally published in 1983.

Dallas, E. S. 1852. Poetics, an Essay on Poetry. London.

Davis, Gregson. 1991. Polyhymnia: The Rhetoric of Horatian Lyric Discourse. Berkeley, CA.

Derrida, Jacques. 1973. Speech and Phenomena and Other Essays on Husserl's Theory of Signs, translated by D.B. Allison. Evanston, IL.

Edmunds, Lowell. 1982. "The Latin Invitation Poem. What Is It? Where Did It Come From?” AJP 103: 184-8.

- 2001. Intertextuality and the Reading of Roman Poetry. Baltimore.

Faraone, Christopher A. 1995. "The 'Performative Future' in Three Hellenistic Incantations and Theocritus' Second Idyll.” CP 90: 1-15.

Fraenkel, Eduard. 1957. Horace. Oxford.

Frye, Northrop. 1985. "Approaching the Lyric." In Lyric Poetry: Beyond New Criticism, edited by C. Hošek and P. Parker, pp. 31-7. Ithaca, NY. 
Genette, Gérard. 1992. The Architext: an Introduction. Berkeley, CA.

Gildersleeve, Basil L. and Gonzalez Lodge. 1895. Latin Grammar. New York.

Gold, Barbara K. 1992. "Openings in Horace's Satires and Odes: Poet, Patron and Audience." YCS 29: 161-85.

Heidegger, Martin. 1996. Being and Time, translated by J. Stambaugh. Albany, NY.

Heinze, Richard. 1923. "Die Horazische Ode." Neue Jahrbücher 51: 153-68.

Hermann, Gottfried. 1877. "De Horatii Primo Carmine Dissertio." In Godofreddi Hermanni Opuscula, edited by T. Fritzsche, v. 8, pp. 395-404. Leipzig.

Johnson, W.R. 1982. The Idea of Lyric: Lyric Modes in Ancient and Modern Poetry. Berkeley, CA.

Kiessling, Adolf and Richard Heinze. 1955. Q. Horatius Flaccus: Oden und Epoden. 11th ed. Original publication 1908. Berlin.

Klingner, Friedrich. 1965. Römische Geisteswelt. Munich.

Kovacs, P. David. 2010. "The Second Person Indefinite and the Logic of Horace, Odes 1.1.29-36." Philologus 154: 306-15.

Kühner, Raphael. 1878. Ausführliche Grammatik der lateinischen Sprache, Bd. 2, Ab. 1. Hannover.

Lowrie, Michèle. 1997. Horace's Narrative Odes. Oxford.

_- 2006. "Hic and Absence in Catullus 68." CP 101: 115-32.

_- 2007. "Horace and Augustus." In Cambridge Companion to Horace, edited by S.J.

Harrison, pp. 77-89. Cambridge.

——.2009a. Horace: Odes and Epodes. Oxford Readings in Classical Studies. Oxford.

- - 2009b. Writing, Performance and Authority in Augustan Rome. Oxford.

Lyne, R. O. A. M. 1995. Horace: Behind The Public Poetry. New Haven, CT.

Mindt, Nina. 2007. Die meta-sympotischen Oden und Epoden des Horaz. Göttingen.

Moles, John L. 2002. “Reconstructing Plancus (Horace, C. 1.7).” JRS 92: 86-102.

Nisbet, R. G. M. and Margaret Hubbard. 1970. A Commentary on Horace: Odes, Book I. Oxford.

- - 1978. A Commentary on Horace: Odes, Book II. Oxford.

Nisbet, R.G.M. and Niall Rudd. 2004. A Commentary on Horace: Odes, Book III. Oxford.

Oliensis, Ellen. 1998. Horace and the Rhetoric of Authority. Cambridge.

Palmer, L. R. 1954. The Latin Language. London.

Peerlkamp, P. H. 1834. Q. Horatii Flacci Carmina. Haarlem.

Pfeijffer, I. L. 1999. First Person Futures in Pindar. Hermes Einzelschriften 81. Stuttgart.

Pomeroy, A. J. 1980. “A Man at a Spring: Horace, Odes 1.1." Ramus 9: 34-50.

Pöschl, Viktor. 1991. Horazische Lyrik: Interpretationen. Heidelberg. Originally published in 1970

Quinn, Kenneth. 1963. Latin Explorations: Critical Studies in Roman Literature. London. - - 1980. Horace: Odes. London.

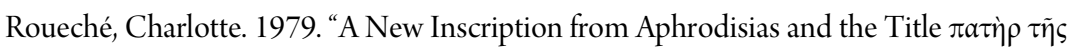




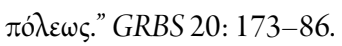

Shackleton Bailey, D. R. 1985. "Vindiciae Horatianae." HSCP 89: 153-70.

—_.2001. Horatius: Opera.4th ed. Original publication 1984. Stuttgart.

Stolz, Friedrich. and Joseph Hermann Schmalz. 1900. Lateinische Grammatik. 3rd ed. Original publication 1885. Munich.

Sutherland, Elizabeth. 2002. Horace's Well-Trained Reader: Towards a Methodology of Audience Participation in the Odes. New York.

Syme, Ronald. 1963. The Roman Revolution.3rd ed. Original publication 1939. Oxford.

Syndikus, H. P. 1972. Die Lyrik des Horaz: Eine Interpretation der Oden, Band I. Darmstadt.

__ 1973. Die Lyrik des Horaz: Eine Interpretation der Oden, Band II. Darmstadt.

Traina, Alionso. 1973. "Semantica del Carpe Diem." RFIC 101: 5-21.

Weiss, Michael. 2009. Outline of the Historical and Comparative Grammar of Latin. Ann Arbor, MI.

West, David. 1967. Reading Horace. Edinburgh.

Williams, Gordon. 1969. The Third Book of Horace's Odes. Oxford.

Woodman, A. J. and R. H. Martin. 1996. The Annals of Tacitus: Book 3. Cambridge. 